\title{
Spiritual needs experienced by the patient's family caregiver under Oncology palliative care
}

Necessidades espirituais vivenciadas pelo cuidador familiar de paciente em atenção paliativa oncológica Necesidades espirituales vivenciadas por el cuidador familiar del paciente en atención paliativa oncológica

Renata Carla Nencetti Pereira Rocha', Eliane Ramos Pereira', Rose Mary Costa Rosa Andrade Silva',
Angelica Yolanda Bueno Bejarano Vale de Medeiros', Sueli Maria Refrande', Neusa Aparecida Refrande'

' Universidade Federal Fluminense, Aurora de Afonso Costa Nursing School. Niterói, Rio de Janeiro, Brazil.

How to cite this article:

Rocha RCNP, Pereira ER, Silva RMCRA, Medeiros AYBBV, Refrande SM, Refrande NA. Spiritual needs experienced by the patient's family caregiver under Oncology palliative care. Rev Bras Enferm [Internet]. 2018;71(Suppl 6):2635-42. [Thematic Issue:

Good practices in the care process as the centrality of the Nursing] DOI: http://dx.doi.org/10.1590/0034-7167-2017-0873

Submission: 12-16-2017

Approval: 02-19-2018

\begin{abstract}
Objective: To understand the spiritual needs of the patients' family caregiver under Oncology palliative care. Method: A descriptive, qualitative study with 20 family caregivers of patients hospitalized in an Oncology palliative unit. The data were collected through a phenomenological interview, and analyzed by the method of Amadeo Giorgi supported in the Merleau-Ponty's Phenomenology of Perception. Results: The categories were unveiled: "Spirituality as a foundation for life"; "Spiritual needs sublimated by the family caregiver"; and "Care expected by the nurse". Conclusion: Family caregivers appropriate spirituality as a coping strategy and meeting the purpose and meaning of the moment experienced. It is profitable for the nurse to contemplate the spiritual needs of the caregiver in order to provide a guided assistance in the humanization of care and comprehensive care. Therefore, there is a need for new studies that address this dimension to the family caregiver in the field of Oncology, since this care is incipient by the nurse.
\end{abstract}

Descriptors: Spirituality; Palliative Care; Neoplasia; Nursing; Caregivers.

\section{RESUMO}

Objetivo: Compreender as necessidades espirituais do cuidador familiar de pacientes em atenção paliativa oncológica. Método: Estudo descritivo, qualitativo, realizado com 20 cuidadores familiares de pacientes internados em uma unidade paliativa oncológica. Os dados foram coletados através de entrevista fenomenológica, e analisados pelo método de Amadeo Giorgi respaldado na fenomenologia da percepção de Merleau-Ponty. Resultados: Desvelaram-se as categorias: "A espiritualidade como alicerce à vida"; "Sublimando as necessidades espirituais do cuidador"; e "Cuidado esperado da Enfermagem na perspectiva do familiar". Conclusão: Cuidadores familiares se apropriam da espiritualidade como estratégia de enfrentamento e encontro do propósito e significado ao momento vivenciado. Torna-se profícuo que o enfermeiro contemple as necessidades espirituais do cuidador no sentido de prestar uma assistência pautada na humanização do cuidado e integralidade da assistência. Para tanto, há necessidade de novos estudos que abordem essa dimensão ao cuidador familiar no campo da Oncologia, visto este cuidado ser incipiente pelo enfermeiro.

Descritores: Espiritualidade; Cuidados Paliativos; Neoplasias; Enfermagem; Cuidadores.

\section{RESUMEN}

Objetivo: Comprender las necesidades espirituales del cuidador familiar de pacientes en atención paliativa oncológica. Método: Estudio descriptivo, cualitativo, realizado con 20 familiares cuidadores de pacientes internados en una unidad paliativa oncológica. Los datos fueron recogidos por medio de una entrevista fenomenológica y analizados por el método de Amadeo Giorgi con respaldo en la fenomenología de la percepción de Merleau-Ponty. Resultados: Se desvelaron las categorías: La espiritualidad como cimiento a la vida y Sublimando las necesidades espirituales del cuidador y el cuidado esperado de la enfermería en la perspectiva del familiar. Conclusión: Familiares cuidadores se apropian de la espiritualidad como estrategia de enfrentamiento y encuentro del propósito y significado al momento vivido. Se vuelve provechoso que el enfermero contemple las necesidades espirituales del cuidador en el sentido de prestar una asistencia pautada en la humanización del cuidado e 
integralidad de la asistencia. Para ello, hay necesidad de realizar nuevos estudios que aborden esa dimensión al cuidador familiar en el campo de la oncología, ya que este cuidado es incipiente por el enfermero.

Descriptores: Espiritualidad; Cuidados Paliativos; Neoplasias; Enfermería; Cuidadores.

\section{CORRESPNDING AUTHOR Renata Carla Nencetti Pereira Rocha E-mail: rnencetti@yahoo.com.br}

\section{INTRODUCTION}

Cancer is a serious public health problem where its incidence on the planet has increased by at least $20 \%$ in the last decade. It is a disease that despite scientific and technological progress, still in the $21^{\text {st }}$ century, remains enigmatic and with not totally efficient treatments, occupying a prominent place in chronic and degenerative diseases. In Brazil, of the 600 thousand new cases estimated per year, $60 \%$ is diagnosed in an advanced state and considered as palliative treatment ${ }^{(1)}$.

Palliative care is a modality of care focused on active and total care for patients and their families with the purpose of offering dignity and humanity in the treatment with a view to improving the quality of life in the face of an illness that threatens the continuity of life, for prevention and relief of suffering, pain and other physical, social, psychological and spiritual symptoms ${ }^{(2)}$. Thus, the family caregiver, assuming responsibility for daily and continuous care to the patient, is considered a target of attention since, in general, they also experience physical, emotional, financial, spiritual, material and existential disorders, especially when the care offered is prolonged or the cancer is already advanced ${ }^{(3)}$.

In this sense, family caregivers of patients who are under Oncology palliative care appropriate spirituality as a foundation to support existential issues, stressful events and traumatizing the role played ${ }^{(4)}$. Thus, this spiritual dimension - considered as a complex and multidimensional part of human experience - demarcates profound implications for the well-being of the individual, through the production of behaviors and feelings of faith, trust, hope, love, tranquility and inner peace, especially when confronted with an illness, loss, suffering and death ${ }^{(5-6)}$.

Spirituality, therefore, is a universal and intrinsic dimension of the human being, since it involves human meanings, purposes and values in the search for meaning for its existence, without necessarily having a mediate connection with a religious institution $^{(4)}$. It is the personal search for the meaning and purpose of fundamental questions of life, as well as the way the individual expresses a state of connection with himself/ herself, with the moment, with others, with nature, and with the sacred/transcendent ${ }^{(7)}$.

It can be affirmed that a series of discussions and debates about contributions of spirituality in the life of people in moments of confrontation of diseases, as well as their influence in the physical, mental and social health has already been realized. However, few studies address care in this dimension to family caregivers by nurses.

In view of the above, the following concerns arose: What are the spiritual needs experienced by the family caregiver of cancer patients who are under palliative care?

The study is relevant because it meets research priorities according to the National Agenda of Priorities in Health Research ${ }^{(8)}$, thus aligning the expression of knowledge to Nursing care and the specificity of the proposal for palliative care that includes family members as a unit of care, contemplating the needs of care specifically in the spiritual dimension for the sake of comprehensive care.

\section{OBJECTIVE}

To understand the spiritual needs experienced by family caregivers of cancer patients under palliative care.

\section{METHOD}

\section{Ethical aspects}

Since it was a question of research involving human beings, it complied with the legal provisions contained in Resolution $466 / 2012^{(9)}$ of the National Health Council (Coselho Nacional de Saúde), which began after the approval and approval of the Research Ethics Committee of the proposing institution, Universidade Federal Fluminense and the co-participant institution, National Cancer Institute.

The study participants were duly informed about the purpose, proposed objectives, secrecy of the information and guarantee of the preservation of anonymity. The interview itself began after the acceptance of participation in the study and signing of the Free and Informed Consent Term.

\section{Type of study and theoretical-methodological framework}

This is a descriptive study with a qualitative approach and support of the Merleau-Ponty Phenomenology Perception that seeks to understand the meanings that subjects attribute to their experiences through perception. In order to achieve this goal, Merleau-Ponty proposes the "back to the things themselves" with a return to the world as it arises before consciousness ${ }^{(10)}$. It is a movement back to the pre-reflective world to seek to understand it before any investigation, explanation or interpretation.

The founding conception in Merleau-Ponty's Phenomenology of Perception is in the quest for the essences in existence, considering man and the world from their feasibility. In it erects perception as the primordial relation of the subject to the world. In this way, perception is conceived as the background where all acts stand out and it is presupposed by them. This perception comes to the fore as a return to one's own direct experience of things, to the origin of significations, to the sense of the senses, and to the source of all thoughts because it is based on man's vision as being in the world ${ }^{(11)}$.

In this sense, the man is everywhere that his perception and that his memory can lead him. The subject, as a being in the world, realizes that nothing absolutely exists, but that everything temporalizes itself, that is, man constructs the experiences 
through the experience of time in his body. In fact, we are temporalities, subjects that live the lived time and this causes that we inhabit in our own act ${ }^{(10)}$.

Thus, in search of the understanding of the human being before his perspective, this methodology approaches the path of the Nursing profession that visualizes the man in his existential totality, not reducing it to biophysical dimensions only. Given this premise, Merleau-Ponty's Phenomenology of Perception, as a methodological strategy, focuses on highlighting spiritual needs as an event that can be understood through perceptual descriptions of study participants.

\section{Research setting}

The eligible field of research was the hospitalization sector of a hospital unit specialized in palliative care, belonging to a national reference center for cancer treatment, located in the state of Rio de Janeiro.

\section{Data source}

Participants in the study were 20 primary family caregivers of patients admitted to a cancer palliative care unit. The number of caregivers interviewed was supported by the saturation of speeches and the objective of the research achieved ${ }^{(12)}$. As inclusion criteria, we have: to be above 18 years of age and to be the main family caregiver of a patient hospitalized in the Palliative Care unit. As exclusion criteria: being a formal caregiver and being a family caregiver with sporadic permanence during the period of hospitalization.

\section{Collection and data organization}

Data collection was performed between January and February of 2017, through a phenomenological interview, using a single open question: What is your perception about your spiritual needs after becoming a caregiver of patients under Oncology palliative care?

The interviews were recorded through the availability of the participants in a reserved room in the own hospitalization sector. To guarantee anonymity, the participants were identified by the letter $\mathrm{C}$ of the word Caregiver and the Arabic numerals corresponding to the order of the interviews, for example $\mathrm{C} 1$ to C20. In addition to the interview technique, a sociodemographic form was used to characterize the participants.

\section{Procedure and data analysis}

After the interviews, we transcribed the speeches of the study participants in full and the search for an understanding of the lived, intentional acts and essences of each family caregiver.

For the analysis and treatment of the data, the phenomenological method of Amadeo Giorgio ${ }^{(13)}$ was applied, working with the experiences of a given phenomenon, assuming four steps: sense of the whole (corresponds to the detailed reading of all the interviews in order to reach the general direction); discrimination of significant units (seeks to focus on the phenomenon studied); transformation of everyday expressions of the subject into psychological language (seeks to modify everyday language to appropriate scientific psychological language); and synthesis of significant units (where all statements are synthesized and structured in a consistent statement of the phenomena observed in relation to the subject's experience).

\section{RESUITS}

The family caregivers interviewed were characterized by being between 25 and 70 years old, with predominance of women $(60 \%)$. Regarding the degree of kinship, $25 \%$ presented themselves as husbands, (20\%) as daughters/sons, (15\%) as wives and the remainder was distributed between companion, mother, sister and father. The option to be caregiver varied in: private option (80\%) and lack of option (20\%). The predominant monthly income was between 1 and 3 minimum wages (60\%). As for religions, $(60 \%)$ professed to have specific religion. Of these, (50\%) declared to be Evangelical, (37.5\%) Catholic, $(69.25 \%)$ Messianic and (6.25\%) Spiritist.

The analysis of the data allowed the apprehension of three thematic categories: "Spirituality as a foundation for life"; "Spiritual needs sublimated by the family caregiver"; and "he care expected by the nurse".

\section{Category 1- Spirituality as a foundation for life}

Regarding the experiences of being a caregiver of patients under Oncology palliative care, relatives develop means through spirituality to transcend obstacles and bring meaning to the lived moment.

The speeches reveal that the participants of the study put their faith in a higher being that assigns a specific plan and mission to each one in a unique and non-transferable way:

God gave it to me, I think he knows my situation. God never forsaken, dishonor. You're always in control. God gave a purpose to me. (C1)

They consider the moment experienced as a unique experience and thank God for the opportunity to be chosen to experience this moment.

It's like a perfect plan of God for our lives. God chose me to enter into his life [patient] and today to be taking care of him. God sees ahead. (C4)

In addition, they address the adversities imposed on the possibility of personal growth and spiritual purification.

For me, it's spiritual growth. It is as if I am being tested for my patience and wisdom. It is a learning to pass on to other people. (C16)

I believe it is for the being to evolve, to be stoned and to evolve spiritually speaking. (C3)

Category 2- Spiritual needs sublimated by the family caregiver To assist in adapting to the challenges posed by illness, family caregivers sustain their spiritual well-being through the contemplation of their spiritual needs. As pointed out by some caregivers, spiritual needs were embedded in affective feelings of love and care as a way to reach fullness: 
If I already gave love, I will give even more now, She was a wonderful mother. So I am and I have to thank for the opportunity to take care of her. (C12)

I give her affection, I give her kisses. She is very cherished. The children kisses her a lot. That's why she's so quiet. (C18)

Hope and forgiveness appear as a positive reinforcement that makes it possible to find a path or exit from the suffering that afflicts the family.

My experience here is that God knows all things. That she'll be cured, right? Medicine is evolved. We say that everything is lost, but it is not! (C6)

We never got along with each other. Do you know that better later than never? I was closer, taking care of her was a way I found to forgive myself. (C14)

Another way to feel consoled and strengthened was linked to faith and belief in a God they serve.

Our strength always comes from God. He is sovereign and keeps me standing. (C4)

I only need divine strength because at the moment I know that he [God] is with me, I have strength! The peace that everyone seeks, can only be found in God. (C2)

Religious rituals were another contribution to their spiritual needs.

I go to church a lot. I pray for strength. (C10)

In my case to calm down I pray and seek the word in the bible. (C19)

I leave here on Sunday at 7:45 am and go to the Cathedral to get the miraculous water. (C6)

The sharing of experiences appears as a positive influence on spiritual well-being as reported below:

I think it's cool to share because you have an open mind and you do not explode. (C7)

It is a way of expressing my feelings, dramas, anguishes and neuras. (C3)

\section{Category 3- Care expected by the nurse}

This category presents the understanding of the primary family caregiver in relation to the care expected by the nurse with an emphasis on his spiritual dimension. In this way, expressive aspects such as interpersonal relationship, communication, affectivity, commitment, empathy, sympathy, love, and compassion were some demands that anchored their care needs.

Sometimes the professional is not so technically skilled, but if he shows an interest in the pain of the other, surely that is the best professional. (C4)
Love overcomes everything. The look is the main thing, it conveys peace. Being well treated too. (C2)

The principle of everything is sincerity and love for the person they are caring for. We feel when the person is loving and then knows that he/she is a good professional. (C1)

Be comprehensive, compassionate. [...], be cosiderate. (C9)

Being affective and receptive was another expectation regarding the care expected.

I think it's cool to come into the room and play, talk, ask if you need anything. Have patience, not be selfish and also put yourself in the other's shoe. (C7)

I wish he could come cheerful and say: - Good morning, my love. I wish he could hug, kiss, be nice, happy, say a good comfort word, raise the spirits of people [caregiver]. (C10)

The interpersonal relationship based on the bond, the sensitive look and the assertive communication was also considered by the caregivers:

People here are very fragile, nervous. So try to understand our side. You are used to seeing the suffering of others, we don't! (C19)

A friendly word, a comfort word, a smile on the face helps a lot. (C5)

Sometimes, clarifying some things, because we are lazy on the subject, explain why it is this way [...].Sometimes we don't know what's going on.. (C13)

\section{DISCUSSION}

In the perspective of the main family caregiver of a patient who is hospitalized in an Oncology palliative care unit, at the center of his or her existence and in his or her singularity, they place themselves before their reality as a being in the world. In this way, they experience situations that can be understood through the Merleau-Ponty' Phenomenology of Perception ${ }^{(10)}$.

Faced with the existentialist foundation, every man has a conscience that will address something or some situation. And it is in this intentionality that the individual has the capacity to understand the unique and singular meaning hidden in each moment ${ }^{(10)}$. In this way, family members, when evaluating their experience as caregivers, discover meaning for their lives as guides to be free and responsible for their existence. Thus, through the limits and obstacles of life, this freedom becomes present implying choices in the face of possibilities and support as a way to transcend ${ }^{(14)}$.

Anchored in the refuge in God and in the belief that there is a higher power that influences life, leads events and brings a greater purpose to the adversities faced, family members put their position in the world and link the sense of responsibility to the Sacred they serve ${ }^{(15)}$. Thus, this positioning generates a sense of welcome, resilience, security and optimism to break life's setbacks. 
A research showed that spiritual beliefs and religious conceptions have a strong influence on the elevation of well-being with consequent reduction of the overload and improvement of the quality of life of the caregivers ${ }^{(16)}$. The literature emphasizes that these resources of spirituality have the potential to deactivate the sympathetic nervous system, reducing the inflammatory cytokines of the blood with consequent reduction of symptoms of anxiety and depression ${ }^{(17)}$. In this way, the level of spirituality has the potential to interfere with the physical and emotional health of caregivers, contributing to a more positive and effective interpretation of life events ${ }^{(18)}$.

Although religiosity and spirituality are seen as synonymous, spirituality encompasses a broad concept by referring to the aspect of the human condition, which relates to the way in which individuals seek and express meaning, purpose to life and reason to live ${ }^{(4,7)}$. Religion presents itself as a moral code of conduct delineated by a specific set of beliefs, rituals, and symbols related to faith, to facilitate closeness to the sacred or transcendent ${ }^{(7)}$. In the study, it was evidenced that religion was used as a fuel of spirituality so that caregivers could express their values, beliefs and practices of faith, implying in redefinitions in the face of the experience of the disease.

Turning to the positive and negative aspects of spirituality/ religiosity, an exploratory study of a qualitative character with 20 elderly people with chronic illness emphasized in their results that belonging to a specific religion is not what defines the improvements or losses of spirituality, but having a good relationship with the "higher self" of their belief contributes significantly to strengthening resilience in the face of adversity ${ }^{(19)}$.

In addition to the presumed benefits of religious involvement in health, studies show that when religious beliefs and behaviors are compromised, they can have harmful consequences for the individual, such as: questioning the existence, questioning the relationship with the Divine, and considering the experience as divine punishment ${ }^{(20)}$. Thus, it is necessary for the nurse to be aware of how religiosity influences this experience so that this resource is a positive tool in its clinical practice.

Already the spirituality understood to give meaning to life, in the perspective of the caregiver, is brought as a point of mutation. Being thus considered as beings in the world, they act as a redefinition of values and attitudes towards life and death and deep spiritual growth. Therefore, what gives meaning to life through lived experience encompasses a range of meanings for the individual to have the motivation to move forward and foster their existence.

In this way, the search for meaning turns to human subjectivity, through the back "to the things themselves", that is, how things appear to each through consciousness ${ }^{(10)}$ and, in the case of the family caregiver, description of their concrete and human needs which brings them back to a sense of the subjective moment experienced.

In the second category, it was synthesized that one of the ways to reach fullness and transcend their existence was to meet their spiritual needs. These variables motivate the human being to meet the meaning and purpose of life ${ }^{(5)}$, besides helping to transcend the difficult moment experienced.

The study identified that spiritual needs were tied to affective retribution, such as giving and receiving love and feelings related to hope, forgiveness, and compassion toward the patient. Also, following a specific religion or faith and sharing the experiences with others who share the same story were also some of the needs mentioned. Therefore, spirituality works as a buffer to support the well-being of the caregiver, protecting him/her from adverse effects on his health, revealing a significant improvement in the quality of life of family caregivers ${ }^{(18)}$.

Spiritual well-being based on the capacity of involvement, perception and what is affected around the being, makes of its variables as an alternative to personal satisfaction. Thus, the transmutation of feelings such as love, affection, zeal and admiration for the loved one during the process of caring for him/her become a source of motivation and meaning for the caregivers' lives ${ }^{(6)}$.

By giving spirituality a dynamic character, subjective and intrinsic to the human being, spiritual needs are also closely related to different beliefs, values and transcendence ${ }^{(21)}$. From this, it was possible to identify that faith and connection with the higher being/spiritual force bring to the individual wellbeing and balance between body, mind and soul, influencing harmoniously in actions, thoughts and feelings.

Thus, faith correlated with measures of religiosity can in fact provide transcendence, redefinition of various aspects of life, feelings of self-esteem, hope, happiness and better connection with the other by establishing bonding and social support ${ }^{(19)}$.

Results from a study of 70 family caregivers of patients showed that although cancer provided increased existential concerns, religious beliefs allowed them to keep them adjusted for their overall well-being ${ }^{(18)}$. In relation to spiritual activities as a form of spirituality, prayers, reading the Bible and participating in religious activities (cults and masses), were reported in the study and were the most evident form of faith exercise.

The sharing of experiences was another way of addressing the spiritual dimension of caregivers. Studies show that sharing experiences is a measure of social support that stimulates interaction between people living in the same situation, as well as being a valuable source of information and expression of feelings, needs, expectations, anxieties and self-care ${ }^{(22)}$.

Therefore, spiritual needs are inseparable from the essential imperatives of the individual, integrating aspects, cognitive, behavioral and experiential. In this way, they include feelings and attitudes with intense inferences in well-being with the transmission of comfort, inner peace and meanings of life.

Thus, it was evidenced that the spiritual needs, when contemplated, corroborate as strong mediators between the demands of care and care provided by caregivers familiar to their sick entity. In this perspective, the path traveled is often centered on feelings of loss, fear, suffering, alteration of daily life and overload $^{(23)}$ with direct interference in the way this dimension is met.

Faced with this perspective, family as "being-in-the-world" attribute meanings and needs to their experiences and, according to the meaning applied to their existence and that this meaning is influenced by their temporality that articulates as beings that are in the world ${ }^{(10)}$. Thus, it has been identified that caregivers are embodied beings who experience their world each of their point of view, but who are also influenced by the world of other caregivers since sharing experiences, share the same world. 
It is emphasized that the understanding of human existence and its needs does not happen immediately. They are constituted in time by the articulations of the meanings that as beings-in-theworld, express to the world ${ }^{(10)}$. Under this view, the individual attributes meaning to things through what is related in the scope of his existence ${ }^{(11)}$. In addition, caregivers were identified as embodied beings ${ }^{(10)}$, because they experience their world each in their own way, but also suffer from the influence of the world of other caregivers since, sharing experiences, they share the same world.

The third category showed that the satisfaction in the context lived by family caregivers is directly related to the expectations regarding the care expected by the nurse with an emphasis on the spiritual dimension. The expected Nursing care for caregivers goes beyond the meaning of scientifically based therapeutic techniques. It involves a careful relationship based on compassion, love, sincerity and compassion.

The attendance of their needs was based on the nurses' appreciated attitudes, such as having joy, being tolerant, playful, affectionate, sympathetic, sensitive and having good communication. Therefore, the key to providing spiritual care is in the irremediable recognition of what spirituality means to the person being cared for ${ }^{(24)}$.

The reports turn directly to the importance of interpersonal relationships through sensitive listening, vigorous gaze and assertive communication. Therefore, it is necessary to consider treatment as the way people establish relationships with one another, it is one of the key foundations for creating a relationship of trust, commitment and respect for human dignity ${ }^{(23)}$.

Based on this relationship, the spiritual care of the nurse is intertwined in the care needs of caregivers, characterizing oneself as one who provides attention to the subjective and spiritual worlds of each individual and which are composed of perceptions, assumptions and feelings that need to be adjusted to their transcendence ${ }^{(24)}$.

Thus, the current perspective of Nursing care is in promoting transpersonal efforts with an emphasis on more altruistic, social and spiritual care. Care becomes a human connection between the professional and the one being cared for and together form a single element in tune ${ }^{(25)}$. In this way, the major purpose is to reach deeper sources of assistance such as protecting, improving and preserving the dignity, humanity, integrity and inner harmony of people.

A study developed with relatives of patients suffering from cancer revealed that Nursing care needs were linked to the nurse's way of being and acting. Among the aforementioned care, empathy, good humor, tranquility, competence, ability, agility and communication were valued ${ }^{(26)}$. Therefore, health care should be more attentive in uniting humanistic factors with scientific knowledge, since the central point of care has been focused on the subjective and emotional aspects of the being.

Turning to the nurses' knowledge about spirituality, a diversity of beliefs and values is found, interfering with their clinical practice ${ }^{(4-5,27)}$. However, a study whose objective was to describe a model of professional practice focused on the spiritual dimension explained that, in common agreement, they value spiritual care through some attitudes and actions in their clinical practice ${ }^{(28)}$. These values were guided by the recognition of human dignity, kindness, compassion, calm, tenderness and care of the nurses for themselves and for the other, corroborating with the transpersonality in the care that seeks the holistic care and comprehensiveness of being ${ }^{(28-29)}$.

It is important to note that for a better systematization of Nursing care, diagnoses referring to the spiritual/religious needs of patients, families and communities have already been constructed and published by the North American Nursing Diagnostics Association (NANDA) ${ }^{(29)}$. However, the service to the spiritual domain is still incipient by the nurse, being still a challenge for the planning and offer of assistance with quality.

As the main obstacles presented by nurses in embracing this content with their practice, they reside in the understanding of their own spirituality, in the difficulty in confronting their beliefs and values with those being cared for, in the lack of preparation and unavailability of time through the demands of work which are imposed on him/her ${ }^{(24,27,30)}$. Therefore, this conduct ends up developing a deep interpersonal and compassionate connection both with the patients and with the relatives who are the protagonists of their care.

Regarding these considerations, studies suggest the revision of nursing curricula in order to integrate themes that address spirituality in the syllabus contents ${ }^{(24,27)}$. It requires that this approach be carried out in a safe, ethical and based on the moral principles of the individual in order to contemplate in the caring process the biological, mental, emotional and spiritual dimensions of the human being.

Inspired by Merleau-Ponty's phenomenology, the abovementioned care as the perceptual experience of the caregiver is intercorporal ${ }^{(10)}$. This implied intercorporeality of the interpersonal relationship of the caregiver with the nurse allows unlimited possibilities of gestures and expressions, making the relationship with the other in the world lived meaningful and meaningful ${ }^{(11)}$.

Therefore, this intercorporal care is interpreted as something that unfolds continuously and is concretized in the attitude and need for a service based on the knowledge of the other being, in the capacity to promote a singular service and in the relationship of complicity with the other. These factors allow possibilities for transcendence both for the being that cares for and for the being that is cared for, promoting what is most profitable, the humanization in care and comprehensiveness in care.

\section{Study limitations}

The limitations of the study are based on the fact that the study was contextualized only in the hospital admission sector. For purposes of comparison, it is necessary to develop new studies that consider other sectors of the hospital unit, so that family caregivers can benefit from comprehensive and effective care.

\section{Contributions to Nursind and Public Policy}

This study may stimulate health professionals and public authorities to reflect on the need to implement a specific public health policy for the family caregiver of patients under Oncology palliative care, ensuring their constitutional and health rights, since they are considered as a unit of care in this mode of attention. 


\section{FINAL CONSIDERATIONS}

The development of the present study aimed to understand the experiences and spiritual needs of the patient's family caregiver under Oncology palliative care through a phenomenological approach.

Regarding the categories elaborated, it was verified that family caregivers appropriate the spirituality as a coping strategy and support for the meeting of the purpose and meaning of the moment experienced. From this perspective, it was synthesized that the service to spiritual needs is of great relevance because it is linked to the way to reach fullness and transcend its existence. In addition, it was characterized that the satisfaction with the context lived by the family caregivers had a direct relation with the expectations regarding the care expected by the nurse, with emphasis on the spiritual dimension.

The data make it clear that Nursing, within the holistic paradigm of care, has its potential of attending to the multiple dimensions of being and, in front of that, it is observed that the approach to the spiritual dimension has been increasingly essential to its clinical practice. However, studies indicate that this care is still incipient by the nurse and is configured as a challenge for the planning and offering of spiritual care assistance. It is important to point out the need for further studies to examine the role played by the nurse in the spiritual field from the point of view of Oncology, extending this attribute in his/ her work practice in order to fulfill the essence of his/her role as comprehensive and humanized care.

\section{REFERENCES}

1. Brasil. Instituto Nacional de Câncer José Alencar Gomes da Silva. Coordenação de Prevenção e Vigilância. Estimativa 2016: incidência de câncer no Brasil[Internet]. Rio de Janeiro: INCA; 2015[cited 2017 Sep 29]. Available from: http://www.inca.gov.br/ bvscontrolecancer/publicacoes/ Estimativa 2016.pdf

2. Worldwide Palliative Care Alliance. Global atlas of palliative care at the end of life[Internet]. WHO. 2014[cited 2018 Jan 25]. Available from http://www.who.int/nmh/Global_Atlas_of_Palliative_Care.pdf

3. Meneguin S, Ribeiro R. Difficulties of caregivers providing palliative care to patients covered by the Family health strategy. Texto Contexto Enferm[ Internet]. 2016[cited 2018 Jan 22];28(1). Available: from: http://www.scielo.br/pdf/tce/v25n1/en 0104-0707tce-25-01-3360014.pdf

4. Evangelista CB, Lopes MEL, Costa SFG, Abrão FMS, Batista PSS, Oliveira RC. Spirituality in patient care under palliative care: a study with nurses. Esc Anna Nery[Internet]. 2016[cited 2018 Sep 10];20(1):176-82. Available from: http://www.scielo.br/pdf/ean/ v20n1/en_1414-8145-ean-20-01-0176.pdf

5. Castelo-Branco MZ, Brito D, Fernandes-Sousa C. Necessidades espirituais da pessoa doente hospitalizada: revisão integrativa. Aquichan[Internet]. 2014[cited 2017 Aug 20];14(1):100-8. Available from: http://www.redalyc.org/html/741/74130041009/

6. Rocha RCNP, Pereira ER, Sora ABAS, Andrade RMCR. O impacto da espiritualidade frente às adversidades do câncer: revisão integrativa. Nurs[Internet]. 2016[cited 2017 Aug 20];19(218):1346-50. Available from: http://pesquisa.bvsalud.org/portal/resource/ pt/bde-31672

7. Koening HG. Medicina, religião e saúde. O encontro da ciência e espiritualidade. Porto Alegre: L\&PM editores; 2012.

8. Brasil. Ministério da Saúde. Agenda Nacional de Prioridades de Pesquisa em Saúde[Internet]. Brasília; 2015[cited 2017 Apr 16]. Available from: http://brasil.evipnet.org/wp-content/uploads/2017/07/ANPPS.pdf

9. Brasil. Ministério da Saúde. Conselho Nacional de Saúde. Comissão Nacional de Ética em Pesquisa. Resolução nº 466, de 12 de dezembro de 2013: diretrizes e normas regulamentadoras de pesquisa envolvendo seres humanos[Internet]. Brasília; 2013[cited 2017 Sep 03]. Available from: http://conselho.saude.gov.br/resolucoes/2012/Reso466.pdf

10. Merleau-Ponty M. Fenomenologia da Percepção de Merleau-Ponty. São Paulo: Martins Fontes; 2011. 672 p.

11. França Filho JL. Acerca da fenomenologia existencial de Maurice Merleau-Ponty[Internet]. Ilhéus; 2014[cited 2017 Oct 04];77-102. Available from: http://books.scielo.org/id/pcd44/pdf/lima-9788574554440-04.pdf

12. Minayo MCS. Amostragem e saturação em pesquisa qualitativa: consensos e controvérsias. Rev Pesqui Qual[Internet]. 2017[cited 2018 Jan 22];5(7). Available from: http://rpq.revista.sepq.org.br/index.php/rpq/article/ view/82

13. Moreira RB, Souza AM. Contributions of the Phenomenological Empirical Method in studies of psychology in Brazil: integrative review of the literature. Rev Nufen[Internet]. 2016[cited 2018 Jan 22];8(1). Available from: http:// pepsic.bvsalud.org/pdf/renufen/ v8n1/a02.pdf

14. Silva JB, Silva LB. Relação entre religião, espiritualidade e sentido da vida. Rablae[Internet]. 2014[cited 2017 Oct 13];3(2):203-15. Available from: http://www.ies.ufpb.br/ojs/index.php/le/article/viewFile/22107/12148

15. Barbosa RMM, Ferreira JLP, Melo MCB, Costa JM. Spirituality as a coping strategy for families of adult patients in palliative care. Rev SBPH[Internet]. 2017[cited 2017 Oct 20];20(1):165-82. Available from: http://pepsic.bvsalud.org/pdf/rsbph/v20n1/v20n1a10.pdf

16. Oliveira WT, Sales CA, Fernandes CAM, Haddad MCL. Avaliação do bem-estar de cuidadores familiares de adultos com neoplasia maligna no âmbito domiciliar. Rev Eletron Enf[Internet]. 2015[cited 2017 Oct 25];17(2):340-9. Available from: https://www.fen. ufg.br/revista/v17/n2/pdf/v17n2a18.pdf 
17. Oliveira MA, Almeira SS. Psiconeuroimunologia e câncer. In: Albuquerque E, Cabral AS, (Eds.). Psico-oncologia Temas Fundamentais. Lisboa: LIDEL; 2015. p. 15-22.

18. Adams RN, Mosher CE, Cannady RS, Lucette A, Kim Y. Caregiving experiences predict changes in spiritual well-being among family caregivers of cancer patients. Psychooncol[Internet]. 2014[cited 2017 Oct 22];23(10):1178-84. Available from: https://www.ncbi. nlm.nih.gov/pmc/articles/pmid/24839205/

19. Rocha ACAL, Ciosak SI. Chronic disease in the elderly: spirituality and coping. Rev Esc Enferm USP[Internet]. 2014 [cited 2017 Oct 22];48(Spe2):87-93. Available from: http://www.scielo.br/pdf/reeusp/v48nspe2/0080-6234-reeusp-48-nspe2-00087.pdf

20. Matos TDS, Meneguin S, Ferreira MLS, Miot HA. Quality of life and religious-spiritual coping in palliative cancer care patients. Rev Latino-Am Enfermagem[Internet]. 2017[cited 2018 Jan 22];25: e2910. Available from: http:// www.scielo.br/pdf/rlae/v25/01041169-rlae-25-e2910.pdf

21. Cervelin AFN, Kruse MHL. Spirituality and religiosity in palliative care: learning to govern. Esc Anna Nery[Internet]. 2014[cited 2017 Dec 13];18(1):136-42. Available from: http://www.scielo.br/pdf/ean/v18n1/en_1414-8145-ean-18-01-0136.pdf

22. Oliveira GS, Bavaresco M, Rosado SR, Dázio EMR, Fava SMCL, Fillipini CB. Experiences of the family caregiver of a person with intestinal ostomy due to colorectal cancer. Rev Rene[Internet]. 2014[cited 2017 Jul 15];15(1):108-15. Available from: http://www. periodicos.ufc.br/rene/article/viewFile/3093/2377

23. Encarnação JF, Farinasso ALC. A família e o familiar cuidador de pacientes fora de possibilidades terapêuticas: uma revisão integrativa. Semina Cienc Biol Saúde[Internet]. 2014[cited 2016 Nov 06];35(1):137-48. Available from: http://www.uel.br/revistas/uel/index. php/seminabio/article/viewFile/16076/15812

24. Rogers M, Wattis J. Spirituality in nursing practice. Nurs Stand[Internet]. 2015[cited 2016 Nov 06];29(3):51-7. Available from: https://www.ncbi.nlm.nih.gov/pubmed/26015142

25. Savieto RM, Leão ER. Nursing assistance and Jean Watson: a reflection on empathy. Esc Anna Nery[Internet]. 2016 [cited 2017 Apr 30];20(1):198-202. Available from: http://www.scielo.br/pdf/ean/v20n1/en 1414-8145-ean-20-01-0198.pdf

26. Martins CSO, Andrade HR, Vaez AC, Araújo DC, Pinheiro FGMS, Bocard MIB. Communication and humanization: nursing tools in patient care Family oncological. Interfaces Científ Saúde Amb[Internet]. 2017[cited 2017 Apr 30];5(3):77-86. Available from: https://periodicos.set.edu.br/index.php/saude/article/download/2525/pdf

27. Sampaio AD, Siqueira HH. Influência da espiritualidade no tratamento do usuário oncológico: olhar da enfermagem. Ensaios Cienc Biol Agrar Saúde[Internet]. 2016[cited 2017 Jul 15];20(3):153-60. Available from: http://pgsskroton.com.br/seer/index.php/ ensaioeciencia/article/view/4433

28. Meehan TC. Spirituality and spiritual care from a careful nursing perspective. J Nurs Manag[Internet]. 2012 [cited 2017 Jul 15];20(8):990-1001. Available from: https://doi.org/10.1111/j.1365-2834.2012.01462.x

29. Nanda Internacional. Diagnósticos de enfermagem: definições e classificação. 2015-2017. Porto Alegre: Artmed; 2015.488 p.

30. Silva BS, Costa EE, Gabriel IGSPS, Silva AE, Machado RM. Percepção de equipe de enfermagem sobre espiritualidade nos cuidados de final de vida. Cogitare Enferm[Internet]. 2016[cited 2017 Aug 08];21(4):01-08. Available from: http://revistas.ufpr.br/cogitare/ article/view/47146 